\title{
Association between vascular endothelial growth factor promoter polymorphisms and the risk of recurrent implantation failure
}

\author{
SUNG HAN SHIM ${ }^{1 *}$, JUNG OH KIM $^{1,2^{*}}$, YOUNG JOO JEON ${ }^{1,2}$, HUI JEONG AN ${ }^{1}$, HYUN AH LEE $^{1}$, \\ JI HYANG KIM ${ }^{3}$, EUN HEE AHN ${ }^{3}$, WOO SIK LEE ${ }^{4}$ and NAM KEUN KIM ${ }^{1,2}$ \\ ${ }^{1}$ Department of Biomedical Science, College of Life Science, CHA University, Seongnam 13488; \\ ${ }^{2}$ Institute for Clinical Research, CHA Bundang Medical Center College of Medicine, CHA University, Seongnam 13496; \\ ${ }^{3}$ Department of Obstetrics and Gynecology, CHA Bundang Medical Center, CHA University, Seongnam 13497; \\ ${ }^{4}$ Fertility Center of CHA Gangnam Medical Center, CHA University, Seoul 135081, Republic of Korea
}

Received July 18, 2017; Accepted November 11, 2017

DOI: $10.3892 / \mathrm{etm} .2017 .5641$

\begin{abstract}
The objective of the present study was to investigate the association between recurrent implantation failure (RIF) and vascular endothelial growth factor $(V E G F)$ gene polymorphisms that are associated with various female infertility disorders. A total of 116 women diagnosed with RIF and 218 control subjects were genotyped for the $V E G F-2578 \mathrm{C}>\mathrm{A},-1154 \mathrm{G}>\mathrm{A},-634 \mathrm{C}>\mathrm{G}$ and $936 \mathrm{C}>\mathrm{T}$ polymorphisms using a polymerase chain reaction-restriction fragment length polymorphism assay. The VEGF -2578AA genotype was associated with an increased prevalence $(\geq 4)$ of RIF [adjusted odds ratio (AOR) $=2.77 ; 95 \%$ confidence interval $(\mathrm{CI})=1.10-7.02 ; \mathrm{P}=0.031]$, whereas the $V E G F-634 \mathrm{CG}+\mathrm{GG}$ genotype was associated with an increased incidence of total RIF (AOR=2.03; 95\% CI=1.02-4.05; $\mathrm{P}=0.044)$ and $\geq 4 \mathrm{RIF}$ (AOR=3.16; 95\% CI=1.19-8.37; $\mathrm{P}=0.021)$. The results of the haplotype analysis indicated that $-2578 \mathrm{~A} /-1154 \mathrm{~A} /-634 \mathrm{G} / 936 \mathrm{C}$ (AOR=1.76; 95\% CI=1.03-3.00; $\mathrm{P}=0.040$ for total RIF and $\mathrm{AOR}=2.11 ; 95 \% \mathrm{CI}=1.12-3.97 ; \mathrm{P}=0.021$ for $\geq 4 \mathrm{RIF}$ ) was associated with the occurrence of RIF. In addition, it was revealed that there was a significant difference in serum prolactin level associated with the $V E G F-634 \mathrm{C}>\mathrm{G}$ polymorphism
\end{abstract}

Correspondence to: Professor Nam Keun Kim, Department of Biomedical Science, College of Life Science, CHA University, 335 Pangyo-ro, Seongnam 13488, Republic of Korea

E-mail: nkkim@cha.ac.kr

Professor Woo Sik Lee, Fertility Center of CHA Gangnam Medical Center, CHA University, 606-13 Yeoksam-dong, Seoul 135081, Republic of Korea

E-mail:wooslee@cha.ac.kr

*Contributed equally

Key words: vascular endothelial growth factor $-2578 \mathrm{C}>\mathrm{A}$, vascular endothelial growth factor $-1154 \mathrm{G}>\mathrm{A}$, vascular endothelial growth factor $-634 \mathrm{C}>\mathrm{G}$, vascular endothelial growth factor $936 \mathrm{C}>\mathrm{T}$, polymorphism, prolactin, recurrent implantation failure
$(\mathrm{P}=0.013)$. Therefore the findings of the present study indicate that the VEGF -2578AA genotype, $-634 \mathrm{G}$ allele and $-2578 \mathrm{~A} /-1154 \mathrm{~A} /-634 \mathrm{G} / 936 \mathrm{C}$ haplotype may be genetic markers for susceptibility to RIF. However, further studies on $V E G F$ promoter polymorphisms that include an independent randomized-controlled population are required to confirm these results.

\section{Introduction}

Recurrent implantation failure (RIF) refers to when an implanted embryo repeatedly fails to result in the development of an intrauterine gestational sac following embryo transfer (ET), as determined by ultrasonography (1). RIF may simply be defined as two or more continuous implantation failures (2); however, researchers now prefer to define RIF as the failure to maintain a clinical pregnancy following three cycles of ET $(3,4)$. Several causes of RIF have been reported, including embryo, uterine and immunological factors, as well as thrombophilic conditions, however, the genetic mechanisms underlying RIF remain unclear (1).

Embryo implantation is a multifactorial event that depends on the interaction of the blastocyst with the receptive endometrium and consists of molecular signaling by the embryo, followed by apposition and attachment to the endometrium (5). Following the formation of the fetal-maternal interface, the essential second step involves the invasion of the embryo endometrium (6). This invasion induces endometrial angiogenesis, which is promoted by numerous growth factors, including vascular endothelial growth factor (VEGF). VEGF increases vascular permeability and activates endothelial cell proliferation, migration, differentiation and capillary formation (6). The intrauterine concentrations of VEGF during the menstrual cycle were determined in women experiencing infertility and it was revealed that VEGF concentrations are cycle-dependent and increase during the late secretory and premenstrual phases (7). VEGF concentrations are also correlated with levels of insulin-like growth factor-binding protein 1, the decidualization marker of the endometrium (8). Sugino et al (9) examined the expression of VEGF and its receptors throughout the menstrual cycle and in early pregnancy. The 
results revealed that the expression of VEGF and its receptor were higher in the mid-secretory phase compared with the proliferative phase during normal menstrual cycles. There was also a marked expression of VEGF in decidual cells in early pregnancy. The authors concluded that VEGF contributes to the successful implantation and maintenance of pregnancy by increasing vascular permeability or by forming the vascular network in the decidua. Kapiteijn et al (10) cultured human embryos in VEGF-conditioned media as an in vitro model and demonstrated that VEGF induced endometrial angiogenesis in the embryos. The results of these previous studies indicate that VEGF may be a key regulator in angiogenesis and decidualization of the endometrium, which are essential processes for the maintenance of a successful pregnancy.

$V E G F$ is located on chromosome $6 \mathrm{p} 21.3$ and is comprised of eight exons (11). Several single nucleotide polymorphisms (SNPs) have been previously detected in $V E G F$, including $-2578 \mathrm{C}>\mathrm{A},-1154 \mathrm{G}>\mathrm{A},-634 \mathrm{C}>\mathrm{G}$ and $936 \mathrm{C}>\mathrm{T}$, which are associated with altered $V E G F$ expression (12-16). There have been several previous reports that $V E G F$ polymorphisms are associated with the development and prognosis of a variety of obstetrical and gynecological diseases (17-19). Additionally, there have been reports that the $V E G F-1154 \mathrm{G}>\mathrm{A}$ and $-634 \mathrm{C}>\mathrm{G}$ polymorphisms are associated with the occurrence of RIF (20-23), however, only a small number of studies have evaluated the association between other functional VEGF polymorphisms and the incidence rate of $\operatorname{RIF}(24,25)$.

The objective of the present study was to examine whether single VEGF SNPs or the functional VEGF polymorphism haplotype -2578C >A (rs699947), -1154G>A (rs1570360), $-634 \mathrm{C}>\mathrm{G}$ (rs2010963) and 936C $>\mathrm{T}$ (rs3025039) may affect the susceptibility to RIF in Korean females.

\section{Materials and methods}

Study population. Blood samples were obtained from 116 females with RIF [median age (range), 34 years (27-45 years)] and 218 healthy female controls [median age (range); 33 years (24-66 years)]. All study participants were recruited from the Department of Obstetrics and Gynecology of CHA Bundang Medical Center (Seongnam, South Korea) between March 2010 and December 2012.

In the present study, RIF was defined as the failure to achieve pregnancy following the completion of two fresh in vitro fertilization-ET cycles with $>10$ cleaved embryos and serum human chorionic gonadotrophin concentrations $<5 \mathrm{U} / \mathrm{ml}$ 14 days after ET. All embryos were examined by an embryologist prior to transfer and judged to be of a good quality. The male and female partner in each couple experiencing RIF was evaluated. Subjects who were diagnosed with RIF due to anatomical, chromosomal, hormonal, infectious, autoimmune or thrombotic causes were excluded from the present study. Anatomical abnormalities were evaluated using several imaging modalities, including sonography, hysterosalpingogram, hysteroscopy, computerized tomography and magnetic resonance imaging. Karyotyping was conducted using standard protocols to assess chromosomal abnormalities $(26,27)$. Hormonal causes of RIF, including hyperprolactinemia, luteal insufficiency and thyroid disease were excluded by measuring the concentrations of prolactin (PRL), thyroid-stimulating hormone (TSH), free thyroxine, follicle-stimulating hormone (FSH), luteinizing hormone (LH), estradiol (E2) and progesterone in samples of peripheral blood. Lupus anticoagulant and anticardiolipin antibodies were examined according to the protocols of a previous study (28) to exclude lupus and antiphospholipid syndrome as autoimmune causes of RIF. Thrombotic causes of RIF were defined as thrombophilia and were evaluated by the detection of protein $\mathrm{C}$ and $\mathrm{S}$ deficiencies and by the presence of anti- $\alpha 2$ glycoprotein antibodies using methods described in a previous study (29).

The enrollment criteria for the control group included regular menstrual cycles, normal karyotype (46, XX), a history of at least one naturally conceived pregnancy and no history of pregnancy loss, including abortion. Data collection methods for each group were identical.

The study protocol was approved by the Institutional Review Board of CHA Bundang Medical Center on 23 February 2010 (reference no. CHAMC2009-12-120). All study participants provided written informed consent prior to participating in the present study. All the methods applied in the study were performed in accordance with the approved guidelines.

Hormone assays. Blood samples were collected by venipuncture on day 2 or 3 of the menstrual cycle for the measurement of FSH, LH, E2, TSH and PRL levels. Serum was prepared as previously described (30) and hormone levels were determined using either radioimmunoassays [E2 (cat. no., A21854), TSH (cat. no., IM3712) and PRL (cat. no., IM2121); Beckman Coulter, Inc., Brea, CA, USA], or enzyme immunoassays using IMMULITE $^{\circledR} 1000$ Systems (FSH and LH; Siemens AG, Munich, Germany) according to the manufacturer's protocol.

Genotype analysis. Genomic DNA was extracted from whole blood using the G-DEX IIc Genomic DNA Extraction kit (Intron Biotechnology Inc., Seongnam, Korea) and purified using the high-salt buffer method (31). DNA was diluted to $100 \mathrm{ng} / \mu \mathrm{l}$ with $1 \mathrm{X}$ TE (Tris-EDTA) buffer and subsequently $1 \mu \mathrm{l}$ from each sample was used to amplify $V E G F$ polymorphisms. Genotyping was performed by polymerase chain reaction (PCR) restriction fragment length polymorphism using the following primers: $V E G F-2578 \mathrm{C}>\mathrm{A}$ polymorphism forward, 5'-GGATGGGGCTGACTAGGTAAG-3' and reverse, 5'-AGC CCCСТTTTCCTCCAAC-3' to generate a 308-bp (C allele) or 326-bp (A allele) product; $V E G F-1154 \mathrm{G}>\mathrm{A}$ polymorphism forward, 5'-CGCGTGTCTCTGGACAGAGTTTCC-3' and reverse, 5'-CGGGGACAGGCGAGCTTCAG-3' to generate a 173-bp (A allele) or 141-bp (G allele) product; $V E G F-634 \mathrm{C}>\mathrm{G}$ polymorphism forward, 5'-CAGGTCACTCACTTTGCCCCG GTC-3' and reverse, 5'-GCTTGCCATTCCCCACTTGAA TCG-3' to generate a 204-bp (C allele) or 180-bp (G allele) product; VEGF $936 \mathrm{C}>\mathrm{T}$ polymorphism forward, 5'-AAGGAA GAGGAGACTCTGCGCAGAGC-3' and reverse, 5'-TAAATG TATGTATGTGGGTGGGTGTGTCTACAGG-3' to generate a 208-bp (C allele) or 122-bp (T allele) fragment. The thermocycling conditions for each set of primers are presented in Table I and all PCR experiments were performed using an AccuPower ${ }^{\circledR}$ HotStart PCR PreMix (Bioneer Corporation, Daejeon, Korea). VEGF polymorphisms were identified by digesting the $V E G F-2578 \mathrm{C}>\mathrm{A}$ and $-634 \mathrm{G}>\mathrm{C}$ PCR products with the AvaII restriction endonuclease (New England 
Table I. PCR conditions, primers and restrict enzyme used in the present study.

\begin{tabular}{|c|c|c|c|c|c|c|}
\hline \multirow{2}{*}{$\begin{array}{l}\text { Gene } \\
V E G F-2578 \mathrm{C}>\mathrm{A}\end{array}$} & \multirow{2}{*}{$\begin{array}{c}\text { rs\# } \\
\text { rs699947 }\end{array}$} & \multicolumn{3}{|c|}{ PCR condition } & Primer sequence $\left(5^{\prime}-3^{\prime}\right)$ & $\mathrm{R} / \mathrm{E}$ \\
\hline & & $\begin{array}{l}94^{\circ} \mathrm{C} \\
94^{\circ} \mathrm{C} \\
-62^{\circ} \mathrm{C} \\
-72^{\circ} \mathrm{C} \\
72^{\circ} \mathrm{C}\end{array}$ & $\begin{array}{l}5 \mathrm{~min} \\
30 \mathrm{sec} \\
30 \mathrm{sec} \\
30 \mathrm{sec} \\
7 \mathrm{~min}\end{array}$ & 35 cycles & $\begin{array}{l}\text { F: GGATGGGGCTGACTAGGTAAG } \\
\text { R: AGCCCCCTTTTCCTCCAAC }\end{array}$ & AvaII \\
\hline$V E G F-1154 \mathrm{G}>\mathrm{A}$ & rs 1570360 & $\begin{array}{r}94^{\circ} \mathrm{C} \\
94^{\circ} \mathrm{C} \\
-59^{\circ} \mathrm{C} \\
-72^{\circ} \mathrm{C} \\
72^{\circ} \mathrm{C}\end{array}$ & $\begin{array}{l}5 \mathrm{~min} \\
30 \mathrm{sec} \\
40 \mathrm{sec} \\
30 \mathrm{sec} \\
5 \mathrm{~min}\end{array}$ & 38 cycles & $\begin{array}{l}\text { F: CGCGTGTCTCTGGACAGAGTTTCC } \\
\text { R: CGGGGACAGGCGAGCTTCAG }\end{array}$ & $M n l I$ \\
\hline$V E G F-634 \mathrm{C}>\mathrm{G}$ & rs2010963 & $\begin{array}{r}94^{\circ} \mathrm{C} \\
94^{\circ} \mathrm{C} \\
-63^{\circ} \mathrm{C} \\
-72^{\circ} \mathrm{C} \\
72^{\circ} \mathrm{C}\end{array}$ & $\begin{array}{l}5 \mathrm{~min} \\
30 \mathrm{sec} \\
35 \mathrm{sec} \\
30 \mathrm{sec} \\
7 \mathrm{~min}\end{array}$ & 40 cycles & $\begin{array}{l}\text { F: CAGGTCACTCACTTTGCCCCGGTC } \\
\text { R: GCTTGCCATTCCCCACTTGAATCG }\end{array}$ & AvaII \\
\hline$V E G F 936 \mathrm{C}>\mathrm{T}$ & rs3025039 & $\begin{array}{r}94^{\circ} \mathrm{C} \\
94^{\circ} \mathrm{C} \\
-68^{\circ} \mathrm{C} \\
-72^{\circ} \mathrm{C} \\
72^{\circ} \mathrm{C}\end{array}$ & $\begin{array}{l}5 \mathrm{~min} \\
30 \mathrm{sec} \\
1 \mathrm{~min} \\
30 \mathrm{sec} \\
7 \mathrm{~min}\end{array}$ & 35 cycles & $\begin{array}{l}\text { F: AAGGAAGAGGAGACTCTGCGCAGAGC } \\
\text { R: TAAATGTATGTATGTGGGTGGGTGTGTCTACAGG }\end{array}$ & NlaIII \\
\hline
\end{tabular}

PCR, polymerase chain reaction; rs\#, RefSNP(rs) number; R/E, restriction enzyme; VEGF, vascular endothelial growth factor; F, forward primer; R, reverse primer.

BioLabs, Inc., Ipswich, MA, USA) and the VEGF -1154G>A and $936 \mathrm{C}>\mathrm{T}$ PCR products with $\mathrm{MnlI}$ and NlaIII restriction endonucleases (New England BioLabs, Inc., Ipswich, MA, USA). All restriction digests were performed at $37^{\circ} \mathrm{C}$ for $16 \mathrm{~h}$ and detected using gel electrophoresis with $3 \%$ agarose gel and visualized with ethidium bromide on a Gel-Doc XR+ version system (Bio-Rad, Hercules, CA, USA).

Statistical analysis. Differences in the genotype and haplotype frequencies between RIF subjects and controls were compared using multivariate logistic regression. Allelic frequencies were calculated to identify deviations from Hardy-Weinberg equilibrium (HWE), using $\mathrm{P}<0.05$ as the significance threshold as previously described $(32,33)$. Adjusted odds ratios (AORs) and $95 \%$ confidence intervals (CI) were used to measure the strength of the association between different genotypes and RIF. Association analysis was performed among groups that were stratified by implantation failure number. Patients with RIF were defined as those with $\geq 2$ implantation failures and patients were divided into the following groups: Total RIF, $\geq 3$ implantation failures ( $\geq 3 \mathrm{RIF}$ ) and $\geq 4$ implantation failures ( $\geq 4 \mathrm{RIF}$ ). As there was no significant difference between the $\geq 3$ RIF group and the total RIF group, the $\geq 4$ RIF group was compared with the total RIF group. $\mathrm{P}<0.05$ was considered to indicate a statistically significant difference. Differences in hormone concentrations (E2, FSH, LH, PRL and TSH) in accordance with $V E G F$ genotypes and alleles were evaluated using a one-way analysis of variance with a post-hoc Scheffé test for all pairwise comparisons and independent two-sample $\mathrm{t}$-tests as appropriate. Data are presented as the mean \pm standard deviation. Statistical analyses were performed using GraphPad Prism version 4.0 (GraphPad Software, Inc., La Jolla, CA, USA), StatsDirect version 2.4.4 (StatsDirect Ltd., Altrincham, UK) and PLINK version 1.07 (http://zzz.bwh.harvard.edu/plink/). Statistical power was calculated using the $\mathrm{G}^{*}$ Power program version 3.1.7 (http://www.gpower.hhu.de/).

Transcription factor binding site prediction. The DNA sequence of the $V E G F$ promoter was used to predict transcription factor binding sites. The P-Match (http://www.gene-regulation.com) $(34,35)$ was used to predict the transcription factors that would bind to the region in VEGF promoter. P-Match is interconnected with the TRANSFAC ${ }^{\circledR}$ database (http://gene-regulation.com/).

\section{Results}

Baseline characteristics and the frequency of VEGF polymorphisms. The demographic characteristics of the study participants are presented in Table II. Patient age and RIF was matched with the relevant control groups and the following characteristics were examined: Age, BMI, gestational age and hormone levels including estradiol, FSH, LH, TSH and PRL. The results demonstrated that there were no significant differences in RIF between patients with RIF and controls. The genotypic distribution and haplotype frequencies of 
Table II. Baseline characteristics of patients with RIF and control subjects.

\begin{tabular}{lccc}
\hline Characteristic & Control subjects $(\mathrm{n}=218)$ & Patients with RIF $(\mathrm{n}=116)$ & P-value \\
\hline Age (years) & $33.34 \pm 5.88$ & $34.22 \pm 3.35$ & 0.127 \\
Body mass index $\left(\mathrm{kg} / \mathrm{m}^{2}\right)$ & $21.77 \pm 3.41$ & $21.05 \pm 2.77$ & 0.081 \\
Previous implantation failure $(\mathrm{n})$ & NA & $4.75 \pm 2.29$ & - \\
Live births $(\mathrm{n})$ & $1.80 \pm 0.74$ & NA & - \\
Gestational age (weeks) & $39.34 \pm 1.66$ & None & - \\
Estradiol $(\mathrm{pg} / \mathrm{ml})$ & NA & $36.06 \pm 961$ & - \\
FSH $(\mathrm{mIU} / \mathrm{ml})$ & NA & $8.60 \pm 4.29$ & - \\
LH $(\mathrm{mIU} / \mathrm{ml})$ & NA & $4.86 \pm 2.31$ & - \\
TSH $(\mathrm{ng} / \mathrm{ml})$ & NA & $2.28 \pm 1.45$ & - \\
PRL $(\mathrm{ng} / \mathrm{ml})$ & NA & $12.78 \pm 6.17$ & - \\
\end{tabular}

Data are presented as the mean \pm standard deviation. RIF, recurrent implantation failure; NA, not applicable; FSH, follicle-stimulating hormone; LH, luteinizing hormone; TSH, thyroid-stimulating hormone; PRL, prolactin.

$V E G F-2578 \mathrm{C}>\mathrm{A},-1154 \mathrm{G}>\mathrm{A},-634 \mathrm{C}>\mathrm{G}$ and $936 \mathrm{C}>\mathrm{T}$ for all study participants are detailed in Table III. The HWE was observed for all $V E G F$ polymorphic sites analyzed in each group. The frequencies of the VEGF -2578CC, -1154GG, $-634 \mathrm{CC}$ and $936 \mathrm{CC}$ genotypes corresponding to the reference genotypes of the four polymorphisms were 51.4, 72.0, 18.8 and $69.3 \%$ in the control group and $48.3,67.2,10.3$ and $67.2 \%$ in the RIF group. Furthermore, the frequency of the VEGF $-2578 \mathrm{C} /-1154 \mathrm{G} /-634 \mathrm{C} / 936 \mathrm{C}$ haplotype was $42.0 \%$ in the control group and $31.9 \%$ in the RIF group. In the present study, patients with RIF exhibited higher frequencies of the $V E G F$ variant genotypes and haplotypes, leading to an increased number of implantation failures, compared with controls.

Genetic susceptibility of single and multiple markers. The AORs for RIF prevalence according to the $V E G F$ genotypes are provided in Table IV. The VEGF -2578AA genotype was associated with a significantly increased prevalence $(\geq 4)$ of RIFs (AOR=2.77; 95\% CI=1.10-7.02; $\mathrm{P}=0.031$ ). The VEGF -634CG+GG genotype was associated with a significantly increased incidence of total RIF (AOR $=2.03$; 95\% $\mathrm{CI}=1.02-4.05 ; \mathrm{P}=0.044)$ and $\geq 4 \mathrm{RIFs}(\mathrm{AOR}=3.16$; $95 \% \mathrm{CI}=1.19-8.37 ; \mathrm{P}=0.021)$. No statistically significant differences were observed between the control and RIF groups for any of the other genotypes.

The linkage disequilibrium of the VEGF polymorphisms at loci -2578(rs699947)/-1154(rs1570360)/-634 (rs2010963)/936(rs3025039) in the RIF and control groups are detailed in Fig. 1. There was a clear linkage disequilibrium between loci -1154 and $-634\left(D^{\prime}=0.945\right)$ and -2578 and $-634\left(D^{\prime}=0.885\right)$ in the control group (Fig. 1A). Polymorphisms $-1154 \mathrm{G}>\mathrm{A}$ and $-634 \mathrm{G}>\mathrm{C}$ had a clear linkage disequilibrium in the RIF group $\left(\mathrm{D}^{\prime}=1.000\right.$; Fig. 1B). The selected haplotypes with the four $V E G F$ polymorphisms were constructed to determine if any specific haplotypes were associated with RIF prevalence (Table IV). The C-G-G-C (AOR=1.59; 95\% CI=1.06-2.39; $\mathrm{P}=0.026$ for total $\mathrm{RIF}$ and $\mathrm{AOR}=2.00 ; 95 \% \mathrm{CI}=1.23-3.26 ; \mathrm{P}=0.006$ for $\geq 4 \mathrm{RIF})$, C-G-G-T (AOR=2.29; 95\% CI=1.10-4.79; $\mathrm{P}=0.027$ for total $\mathrm{RIF})$ and $\mathrm{A}-\mathrm{A}-\mathrm{G}-\mathrm{C}(\mathrm{AOR}=1.76 ; 95 \% \mathrm{CI}=1.03-3.00 ; \mathrm{P}=0.040$ for total RIF and $\mathrm{AOR}=2.11 ; 95 \% \mathrm{CI}=1.12-3.97 ; \mathrm{P}=0.021$ for $\geq 4 \mathrm{RIF}$ ) haplotype frequencies of the $V E G F-2578 \mathrm{C}>\mathrm{A}$, $-1154 \mathrm{G}>\mathrm{A},-634 \mathrm{C}>\mathrm{G}$ and $936 \mathrm{C}>\mathrm{T}$ variants, respectively, were significantly different between the RIF and the control group.

Differences in hormones according to VEGF polymorphisms in the RIF group. Possible associations between RIF and the serum level of PRL were examined. The results are presented in Fig. 2 according to VEGF gene polymorphisms. Patients with the VEGF -634GG genotype had significantly lower serum PRL levels compared with patients with the VEGF -634CC genotype (Fig. 2A). Additionally, patients with the $V E G F-634$ G allele had significantly lower serum PRL levels compared with patients with the VEGF -634C allele (Fig. 2B). Levels of the other hormones investigated (E2, FSH, LH and TSH) were not significantly associated with the polymorphisms examined in the present study (Table V). Table VI summarizes the statistical power of genetic associations in the present case-control study. The analysis of $V E G F-634 \mathrm{C}>\mathrm{G}$ polymorphism was statistically significant when compared with the additive model (94.49\%), dominant model (99.91\%) and recessive model $(94.79 \%)$ for AORs with RIF risk in total RIFs. In $\geq 4$ RIFs, the statistical power of $V E G F-634 \mathrm{C}>\mathrm{G}$ polymorphism was strongly significant when compared with the additive model (99.25\%), dominant model (100\%) and recessive model (99.85\%). In addition, the VEGF $-2578 \mathrm{C}>\mathrm{A}$ polymorphism was demonstrated to possess a greater statistical power than that of the recessive model (99.99\%) in AORs of $\geq 4$ RIFs.

\section{Discussion}

The present study evaluated the association between four functional $V E G F$ SNPs $(-2578 \mathrm{C}>\mathrm{A},-1154 \mathrm{G}>\mathrm{A},-634 \mathrm{C}>\mathrm{G}$ and $936 \mathrm{C}>\mathrm{T}$ ) and the prevalence of RIF in Korean females. The results indicated that the $V E G F-2578 \mathrm{AA}$ genotype, $-634 \mathrm{G}$ allele and $-2578 \mathrm{C} / 1154 \mathrm{G} /-634 \mathrm{G} / 936 \mathrm{C},-2578 \mathrm{C} /-1154 \mathrm{G} /-634 \mathrm{G} / 936 \mathrm{~T}$ and $-2578 \mathrm{~A} /-1154 \mathrm{~A} /-634 \mathrm{G} / 936 \mathrm{C}$ haplotypes may be genetic markers for susceptibility to RIF. 
Table III. Genotype and haplotype frequencies of VEGF polymorphisms.

A, Genotype frequencies

\begin{tabular}{|c|c|c|c|}
\hline \multirow[b]{2}{*}{ Genotype } & \multirow{2}{*}{$\frac{\text { Without RIF }}{\text { Controls, } \mathrm{n}=218(\%)}$} & \multicolumn{2}{|c|}{ With RIF } \\
\hline & & Total RIFs, $\mathrm{n}=116(\%)$ & $\geq 4$ RIFs, $n=72(\%)$ \\
\hline$V E G F-2578 C C$ & $112(51.4)$ & $56(48.3)$ & $33(45.8)$ \\
\hline$V E G F-2578 \mathrm{CA}$ & $95(43.6)$ & $49(42.2)$ & $30(41.7)$ \\
\hline$V E G F-2578 \mathrm{AA}$ & $11(5.0)$ & $11(9.5)$ & $9(12.5)$ \\
\hline$H W E-\mathrm{P}$ & 0.105 & 0.953 & 0.596 \\
\hline$V E G F-1154 \mathrm{GG}$ & $157(72.0)$ & $78(67.2)$ & $46(63.9)$ \\
\hline$V E G F-1154 \mathrm{GA}$ & $53(24.3)$ & $33(28.4)$ & $22(30.6)$ \\
\hline$V E G F-1154 \mathrm{AA}$ & $8(3.7)$ & $5(4.3)$ & $4(5.6)$ \\
\hline$H W E-\mathrm{P}$ & 0.197 & 0.533 & 0.532 \\
\hline$V E G F-634 C C$ & $41(18.8)$ & $12(10.3)$ & $5(6.9)$ \\
\hline$V E G F-634 C G$ & $112(51.4)$ & $56(48.3)$ & $33(45.8)$ \\
\hline$V E G F-634 \mathrm{GG}$ & $65(29.8)$ & $48(41.4)$ & $34(47.2)$ \\
\hline$H W E-\mathrm{P}$ & 0.554 & 0.461 & 0.424 \\
\hline$V E G F$ 936CC & $151(69.3)$ & $78(67.2)$ & $45(62.5)$ \\
\hline$V E G F$ 936CT & $62(28.4)$ & 37 (31.9) & $27(37.5)$ \\
\hline$V E G F$ 936TT & $5(2.3)$ & $1(0.9)$ & $0(0.0)$ \\
\hline$H W E-\mathrm{P}$ & 0.642 & 0.130 & 0.050 \\
\hline
\end{tabular}

B, Haplotype frequencies

\begin{tabular}{|c|c|c|c|}
\hline \multirow[b]{2}{*}{ Haplotype } & \multirow{2}{*}{$\frac{\text { Without RIF }}{\text { Controls }(2 n=436, \%)}$} & \multicolumn{2}{|c|}{ With RIF } \\
\hline & & Total RIFs $(2 \mathrm{n}=232, \%)$ & $\geq 4$ RIFs $(2 n=144, \%)$ \\
\hline$V E G F-2578 \mathrm{C} /-1154 \mathrm{G} /-634 \mathrm{C} / 936 \mathrm{C}$ & $183(42.0)$ & $74(31.9)$ & $40(27.8)$ \\
\hline$V E G F-2578 \mathrm{C} /-1154 \mathrm{G} /-634 \mathrm{C} / 936 \mathrm{~T}$ & $6(1.4)$ & $1(0.4)$ & $0(0.0)$ \\
\hline$V E G F-2578 \mathrm{C} /-1154 \mathrm{G} /-634 \mathrm{G} / 936 \mathrm{C}$ & $107(24.5)$ & $68(29.3)$ & $46(31.9)$ \\
\hline$V E G F-2578 \mathrm{C} /-1154 \mathrm{G} /-634 \mathrm{G} / 936 \mathrm{~T}$ & $17(3.9)$ & $16(6.9)$ & $9(6.3)$ \\
\hline$V E G F-2578 \mathrm{C} /-1154 \mathrm{~A} /-634 \mathrm{C} / 936 \mathrm{C}$ & $1(0.2)$ & $0(0.0)$ & $0(0.0)$ \\
\hline$V E G F-2578 \mathrm{C} /-1154 \mathrm{~A} /-634 \mathrm{C} / 936 \mathrm{~T}$ & $0(0.0)$ & $0(0.0)$ & $0(0.0)$ \\
\hline$V E G F-2578 \mathrm{C} /-1154 \mathrm{~A} /-634 \mathrm{G} / 936 \mathrm{C}$ & $3(0.7)$ & $1(0.4)$ & $0(0.0)$ \\
\hline$V E G F-2578 \mathrm{C} /-1154 \mathrm{~A} /-634 \mathrm{G} / 936 \mathrm{~T}$ & $2(0.5)$ & $1(0.4)$ & $1(0.7)$ \\
\hline$V E G F-2578 \mathrm{~A} /-1154 \mathrm{G} /-634 \mathrm{C} / 936 \mathrm{C}$ & $4(0.9)$ & $5(2.2)$ & $3(2.1)$ \\
\hline$V E G F-2578 \mathrm{~A} /-1154 \mathrm{G} /-634 \mathrm{G} / 936 \mathrm{C}$ & $23(5.3)$ & $14(6.0)$ & $8(5.6)$ \\
\hline$V E G F-2578 \mathrm{~A} /-1154 \mathrm{G} /-634 \mathrm{G} / 936 \mathrm{~T}$ & $27(6.2)$ & $11(4.7)$ & $8(5.6)$ \\
\hline$V E G F-2578 \mathrm{~A} /-1154 \mathrm{~A} /-634 \mathrm{G} / 936 \mathrm{C}$ & $43(9.9)$ & $31(13.4)$ & $20(13.9)$ \\
\hline$V E G F-2578 \mathrm{~A} /-1154 \mathrm{~A} /-634 \mathrm{G} / 936 \mathrm{~T}$ & $20(4.6)$ & $10(4.3)$ & $9(6.3)$ \\
\hline
\end{tabular}

RIF, recurrent implantation failure; HWE, Hardy-Weinberg equilibrium; VEGF, vascular endothelial growth factor.

The $-2578 \mathrm{C}>\mathrm{A}$ and $-1154 \mathrm{G}>\mathrm{A}$ variants are located in the $V E G F$ promoter region (26). The $V E G F-2578 C C$ and -1154GG genotypes appear to confer increased VEGF secretion compared with the presence of a minor allele $(36,37)$. However, the functional effect of $V E G F-634 \mathrm{C}>\mathrm{G}$ is contested. Watson et al (15) and Hansen et al (38) proposed that the VEGF -634C allele was associated with the decreased production of $V E G F$, whereas Wongpiyabovorn et al (16) and Awata et al (39) reported that the VEGF -634G allele was associated with decreased VEGF production. These conflicting results are potentially due to the effect of haplotype combinations. Therefore, based on the VEGF haplotypes containing other VEGF SNPs, the effect of $V E G F-634 C>\mathrm{G}$ should be examined further. It has previously been reported that there is an association between the haplotypes resulting from polymorphisms in the promoter region (-2578/-1154/-634) and $V E G F$ expression (36). Lambrechts et al (36) reported that the $-2578 \mathrm{~A} /-1154 \mathrm{~A} /-634 \mathrm{G}$ and $-2578 \mathrm{~A} /-1154 \mathrm{G} /-634 \mathrm{G} V E G F$ 
Table IV. AORs for RIF prevalence according to VEGF genotype and haplotype.

A, VEGF genotypes

\begin{tabular}{|c|c|c|c|c|c|c|c|c|}
\hline \multirow[b]{2}{*}{ Genotype } & \multirow[b]{2}{*}{ Model } & \multirow[b]{2}{*}{ Reference type } & \multicolumn{3}{|c|}{ Total RIFs } & \multicolumn{3}{|c|}{$\geq 4$ RIFs } \\
\hline & & & AOR $(95 \% \mathrm{CI})$ & $\mathrm{P}$ & Adjusted $\mathrm{P}^{\mathrm{a}}$ & AOR $(95 \% \mathrm{CI})$ & $\mathrm{P}$ & Adjusted $\mathrm{P}^{\mathrm{a}}$ \\
\hline \multirow[t]{3}{*}{$V E G F-2578 \mathrm{C}>\mathrm{A}$} & Additive & $-2578 \mathrm{CC}$ & $1.21(0.84-1.75)$ & 0.303 & 0.606 & $1.39(0.91-2.12)$ & 0.131 & 0.262 \\
\hline & Dominant & $-2578 \mathrm{CC}$ & $1.12(0.71-1.75)$ & 0.637 & 0.764 & $1.23(0.72-2.10)$ & 0.454 & 0.454 \\
\hline & Recessive & $-2578 \mathrm{CC}$ & $2.02(0.85-4.83)$ & 0.113 & 0.226 & $2.77(1.10-7.02)$ & 0.031 & 0.047 \\
\hline \multirow{3}{*}{$V E G F-1154 \mathrm{G}>\mathrm{A}$} & Additive & $-1154 \mathrm{GG}$ & $1.17(0.78-1.75)$ & 0.461 & 0.615 & $1.34(0.84-2.12)$ & 0.215 & 0.287 \\
\hline & Dominant & $-1154 \mathrm{GG}$ & $1.22(0.75-1.99)$ & 0.433 & 0.764 & $1.42(0.81-2.50)$ & 0.225 & 0.427 \\
\hline & Recessive & $-1154 \mathrm{GG}$ & $1.15(0.37-3.62)$ & 0.811 & 0.811 & $1.52(0.44-5.25)$ & 0.504 & 0.504 \\
\hline \multirow[t]{3}{*}{$V E G F-634 \mathrm{C}>\mathrm{G}$} & Additive & $-634 \mathrm{CC}$ & $1.56(1.10-2.19)$ & 0.012 & 0.048 & $1.95(1.28-2.98)$ & 0.002 & 0.008 \\
\hline & Dominant & $-634 C C$ & $2.03(1.02-4.05)$ & 0.044 & 0.176 & $3.16(1.19-8.37)$ & 0.021 & 0.084 \\
\hline & Recessive & $-634 \mathrm{CC}$ & $1.65(1.03-2.65)$ & 0.037 & 0.148 & $2.10(1.22-3.64)$ & 0.008 & 0.024 \\
\hline \multirow[t]{3}{*}{$V E G F$ 936C >T } & Additive & $936 \mathrm{CC}$ & $1.00(0.64-1.56)$ & 0.995 & 0.995 & $1.15(0.69-1.93)$ & 0.587 & 0.587 \\
\hline & Dominant & $936 \mathrm{CC}$ & $1.08(0.66-1.75)$ & 0.764 & 0.764 & $1.33(0.76-2.32)$ & 0.32 & 0.427 \\
\hline & Recessive & $936 \mathrm{CC}$ & $0.32(0.04-2.86)$ & 0.308 & 0.411 & NA & NA & NA \\
\hline
\end{tabular}

B, VEGF haplotypes

Total RIFs

$\geq 4$ RIFs

\begin{tabular}{|c|c|c|c|c|c|c|c|}
\hline \multirow[b]{2}{*}{ Haplotype } & \multirow[b]{2}{*}{ Reference type } & & \\
\hline & & AOR $(95 \% \mathrm{CI})$ & $\mathrm{P}$ & Adjusted $\mathrm{P}^{\mathrm{a}}$ & AOR $(95 \% \mathrm{CI})$ & $\mathrm{P}$ & Adjusted $\mathrm{P}^{\mathrm{a}}$ \\
\hline $\begin{array}{l}V E G F-2578 \mathrm{C} / \\
-1154 \mathrm{G} /-634 \mathrm{C} / 936 \mathrm{~T}\end{array}$ & $\begin{array}{l}-2578 \mathrm{C} /-1154 \mathrm{G} / \\
-634 \mathrm{C} / 936 \mathrm{C}\end{array}$ & $0.38(0.04-3.26)$ & 0.378 & 0.504 & NA & NA & \\
\hline $\begin{array}{l}V E G F-2578 \mathrm{C} / \\
-1154 \mathrm{G} /-634 \mathrm{G} / 936 \mathrm{C}\end{array}$ & $\begin{array}{l}-2578 \mathrm{C} /-1154 \mathrm{G} / \\
-634 \mathrm{C} / 936 \mathrm{C}\end{array}$ & $1.59(1.06-2.39)$ & 0.026 & 0.107 & $2.00(1.23-3.26)$ & 0.006 & 0.042 \\
\hline $\begin{array}{l}V E G F-2578 \mathrm{C} / \\
-1154 \mathrm{G} /-634 \mathrm{G} / 936 \mathrm{~T}\end{array}$ & $\begin{array}{l}-2578 \mathrm{C} /-1154 \mathrm{G} / \\
-634 \mathrm{C} / 936 \mathrm{C}\end{array}$ & $2.29(1.10-4.79)$ & 0.027 & 0.107 & $2.38(0.99-5.75)$ & 0.053 & 0.124 \\
\hline $\begin{array}{l}V E G F-2578 \mathrm{~A} / \\
-1154 \mathrm{G} /-634 \mathrm{C} / 936 \mathrm{C}\end{array}$ & $\begin{array}{l}-2578 \mathrm{C} /-1154 \mathrm{G} / \\
-634 \mathrm{C} / 936 \mathrm{C}\end{array}$ & $3.09(0.81-1.82)$ & 0.100 & 0.200 & $3.34(0.72-15.55)$ & 0.124 & 0.174 \\
\hline $\begin{array}{l}V E G F-2578 \mathrm{~A} / \\
-1154 \mathrm{G} /-634 \mathrm{G} / 936 \mathrm{C}\end{array}$ & $\begin{array}{l}-2578 \mathrm{C} /-1154 \mathrm{G} / \\
-634 \mathrm{C} / 936 \mathrm{C}\end{array}$ & $1.52(0.74-3.12)$ & 0.253 & 0.405 & $1.60(0.67-3.84)$ & 0.292 & 0.174 \\
\hline $\begin{array}{l}V E G F-2578 \mathrm{~A} / \\
-1154 \mathrm{G} /-634 \mathrm{G} / 936 \mathrm{~T}\end{array}$ & $\begin{array}{l}-2578 \mathrm{C} /-1154 \mathrm{G} / \\
-634 \mathrm{C} / 936 \mathrm{C}\end{array}$ & $1.02(0.48-2.16)$ & 0.961 & 0.961 & $1.37(0.58-3.24)$ & 0.475 & 0.341 \\
\hline $\begin{array}{l}V E G F-2578 \mathrm{~A} / \\
-1154 \mathrm{~A} /-634 \mathrm{G} / 936 \mathrm{C}\end{array}$ & $\begin{array}{l}-2578 \mathrm{C} /-1154 \mathrm{G} / \\
-634 \mathrm{C} / 936 \mathrm{C}\end{array}$ & $1.76(1.03-3.00)$ & 0.040 & 0.107 & $2.11(1.12-3.97)$ & 0.021 & 0.475 \\
\hline $\begin{array}{l}V E G F-2578 \mathrm{~A} / \\
-1154 \mathrm{~A} /-634 \mathrm{G} / 936 \mathrm{~T}\end{array}$ & $\begin{array}{l}-2578 \mathrm{C} /-1154 \mathrm{G} / \\
-634 \mathrm{C} / 936 \mathrm{C}\end{array}$ & $1.20(0.53-2.68)$ & 0.666 & 0.761 & $2.01(0.85-4.74)$ & 0.113 & 0.074 \\
\hline
\end{tabular}

${ }^{\text {a}}$ False discovery rate-adjusted P-value for multiple hypotheses testing using the Benjamini-Hochberg method. AOR, adjusted odds ratio; CI, confidence intervals; RIF, recurrent implantation failure; NA, not applicable; VEGF, vascular endothelial growth factor. AORs and P-values were adjusted by age and body mass index.

haplotypes were significantly correlated with decreased $V E G F$ mRNA expression and plasma concentrations.

Among these polymorphisms, the mechanism of $V E G F$ $-2578 \mathrm{C}>\mathrm{A}$ is well known $(36,40,41)$. This SNP is in complete linkage with the deletion/insertion of an 18-bp fragment in the -2549 region and a construct containing the 18-bp deletion (linkage with the $\mathrm{C}$ allele) causing a 1.95-fold increase in transactivation (42). As evidence of the $V E G F-1154 \mathrm{G}>\mathrm{A}$ and
$-634 \mathrm{C}>\mathrm{G}$ function is limited, the transcription factor binding sites containing these SNPs were predicted using P-Match. $V E G F-1154 \mathrm{G}>\mathrm{A}$ is contained within a predicted binding site for myeloid zinc finger-1 (MZF1) in which the MZF1 binding site is substituted for the Pax 2 or Sp1 binding site by $-1154 \mathrm{~A}$ (prediction data attained using P-Match; gene-regulation. com). $V E G F-634 C>\mathrm{G}$ is likewise identified within the predicted MZF1 or Pax2 binding site (prediction data attained 

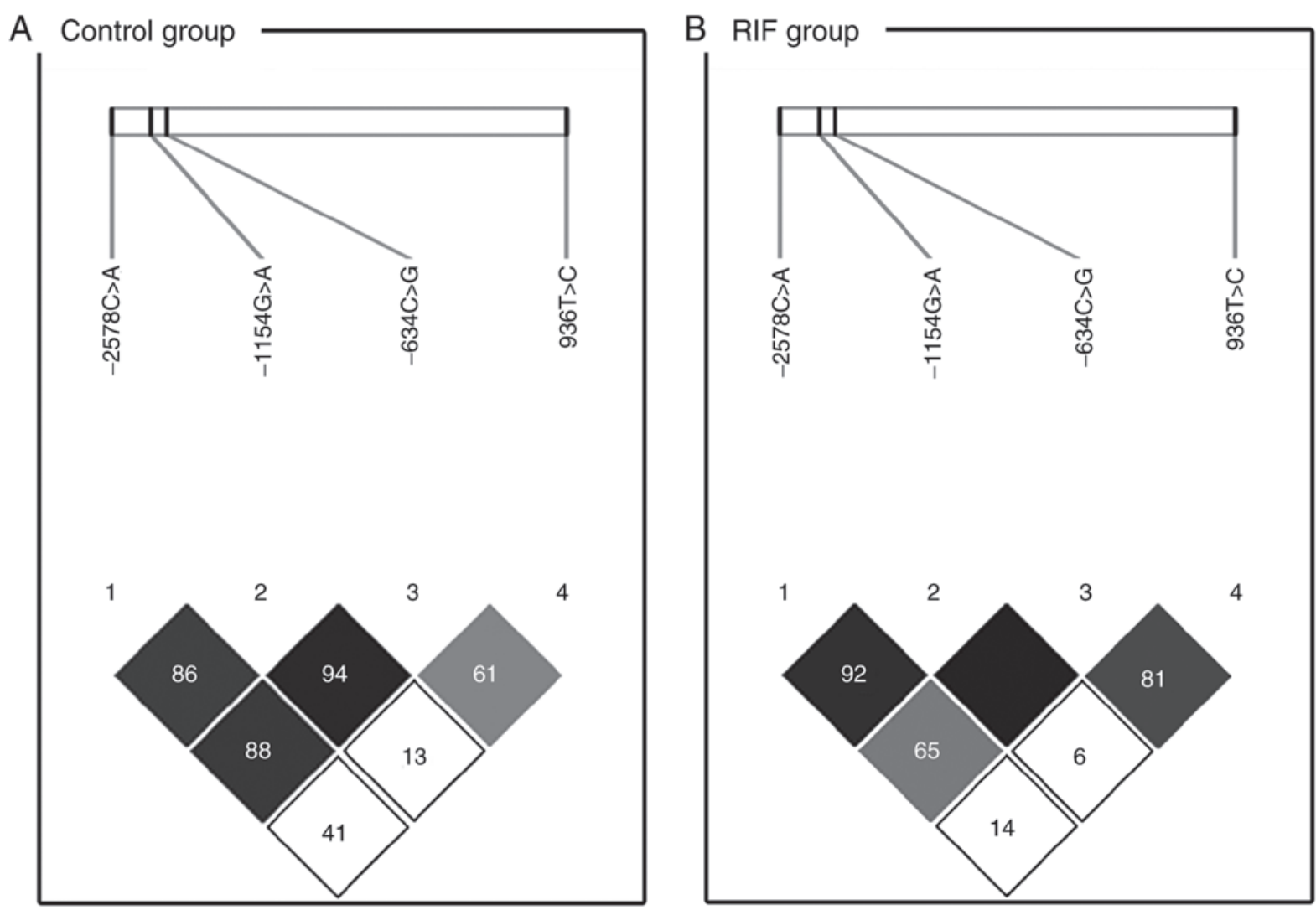

Figure 1. LD patterns of $V E G F$ single nucleotide polymorphisms. The values in the squares denote LD between single markers. (A) Control subjects exhibited strong LD between loci VEGF -1154G >A (rs1570360) and -634C > G (rs2010963; D'=0.945), VEGF -2578C >A (rs699947) and -1154G >A (rs1570360; $\left.\mathrm{D}^{\prime}=0.863\right)$ and $V E G F-2578 \mathrm{C}>\mathrm{A}(\mathrm{rs} 699947)$ and $-634 \mathrm{C}>\mathrm{G}\left(\mathrm{rs} 2010963 ; \mathrm{D}^{\prime}=0.885\right)$. (B) Patients with recurrent implantation failure exhibited strong $\mathrm{LD}$ between loci $V E G F-2578 \mathrm{C}>\mathrm{A}(\mathrm{rs} 699947)$ and $-1154 \mathrm{G}>\mathrm{A}\left(\mathrm{rs} 1570360 ; \mathrm{D}^{\prime}=0.923\right)$ and between $V E G F-1154 \mathrm{G}>\mathrm{A}$ and $-634 \mathrm{C}>\mathrm{G}\left(\mathrm{D}^{\prime}=1.000\right)$. Dark squares indicate high $r^{2}$ values and light squares indicate low $r^{2}$ values. LD, linkage disequilibrium; VEGF, vascular endothelial growth factor.

using P-Match; gene-regulation.com), however, a change in the predicted transcription factor binding sites is not produced by the substitution.

In addition to VEGF, serum levels of the classical decidualization marker PRL should also be considered in association with decidualization of the endometrium. The present study revealed an association between the $V E G F-634 \mathrm{C}>\mathrm{G}$ polymorphism and plasma PRL levels. A previous study reported that $V E G F$ rs $3025039 \mathrm{C}>\mathrm{T}$ was correlated with plasma PRL levels in polycystic ovary syndrome (43). A number of previous studies have also revealed that secreted PRL affects tissue vascularization at the lactation stage and present a role of PRL as a pro-angiogenic factor (44-48). Based on this, the current authors hypothesized that VEGF polymorphisms may affect the plasma PRL levels, however this hypothesis was not clearly confirmed or rejected through the experiments of the present study. Therefore, further studies are necessary to determine the potential association between $V E G F$ polymorphisms and PRL levels.

Furthermore, previous studies have demonstrated that differences in PRL levels affect the formation of the placenta and decidualization of the endometrium following fertilization $(44,49-52)$. PRL also regulates inflammatory cytokine (TNF- $\alpha$, IL- $1 \alpha$, IL-1 $\beta$, TGF- $\beta$ and IL- 8 ) levels and immune system homeostasis in early pregnancy (53-55). Therefore, normal PRL levels are critical for maintaining a successful pregnancy. In addition, PRL regulates gonadal function and serves roles in steroidogenesis, formation of the corpus luteum and modulation of the effects of gonadotropins (55). PRL stimulates the process of ovulation, implantation and placental development $(49-52,56)$. In addition, PRL stimulates the growth, development and metabolism of the fetus, serves key roles in the formation of the corpus luteum, decreases levels of sex steroids during the menstrual cycle and stimulates the production of milk during the postpartum period (57).

The present study had several limitations. Firstly, the serum VEGF levels in the participants were not measured. Although the association between VEGF polymorphisms and serum VEGF levels has been elucidated in other conditions $(36,42)$, the data associated with RIF is limited. Secondly, it was not possible to explain the exact role of VEGF in the pathogenesis of RIF development. Accordingly, in future research an association between the VEGF polymorphisms and VEGF expression in the tissues in which implantation events occur, as opposed to serum concentrations, should be elucidated. VEGF expression occurs within biochemical pathways and is not the only risk factor for disorders associated with implantation and pregnancy maintenance. Therefore, the interactions between VEGF and other factors expressed during implantation are also potential risk factors. To overcome these constraints, further studies on the functional role of $V E G F$ polymorphisms in the pathogenesis of RIF are required. 


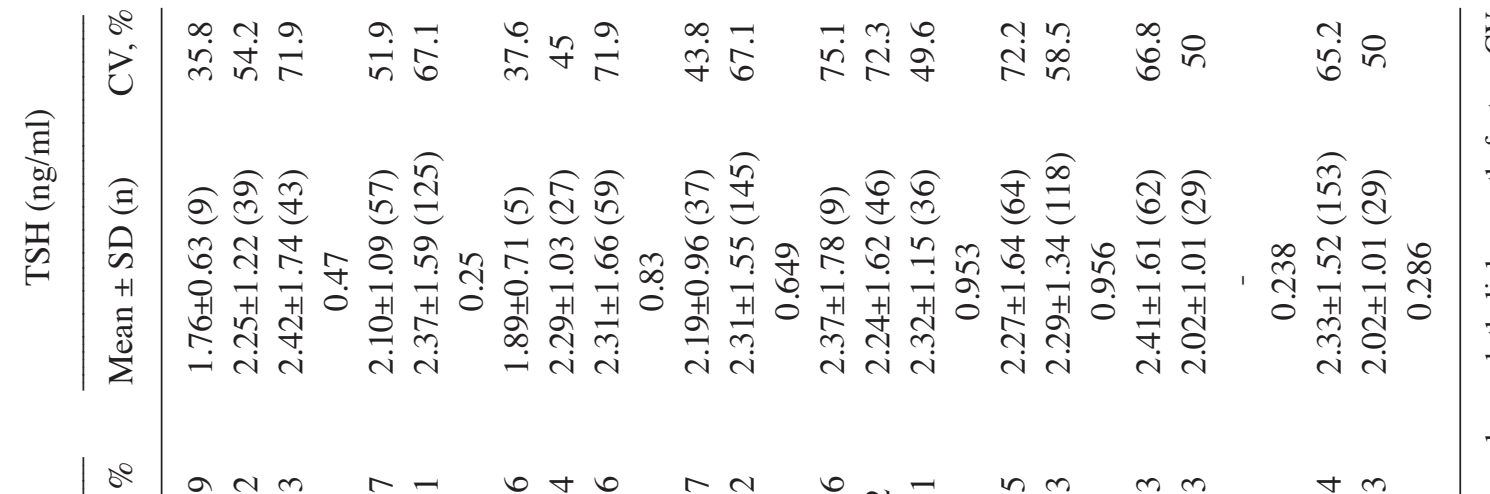

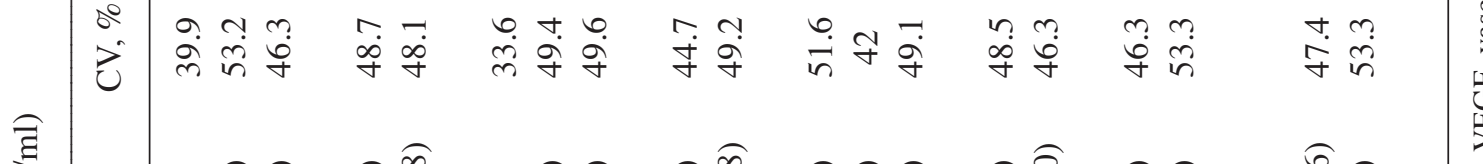

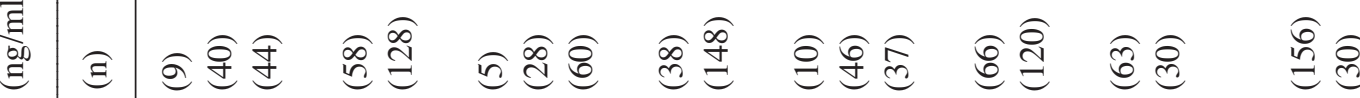

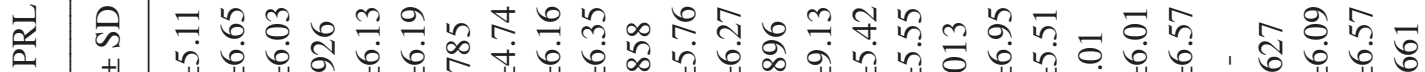

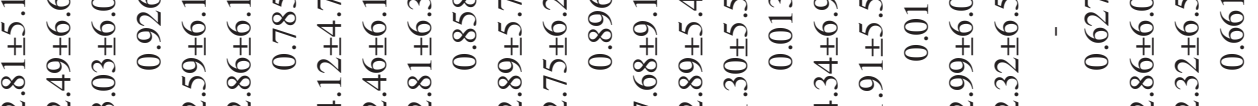

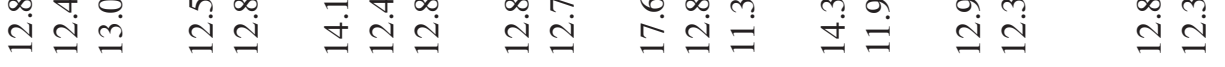

官家字

દิ

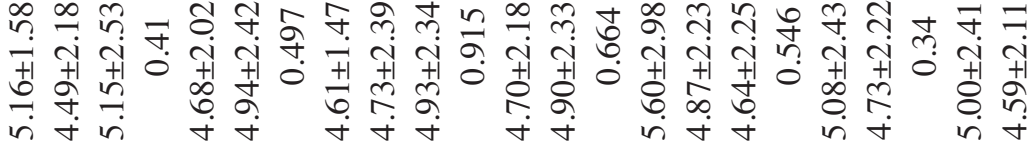

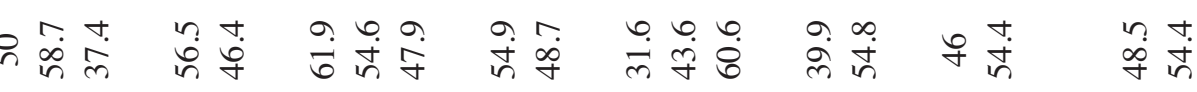

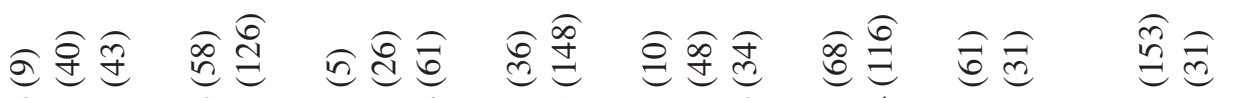
ᄋ

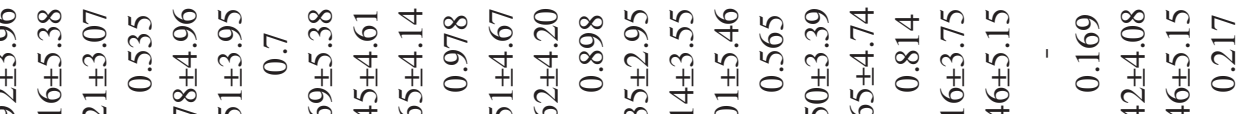

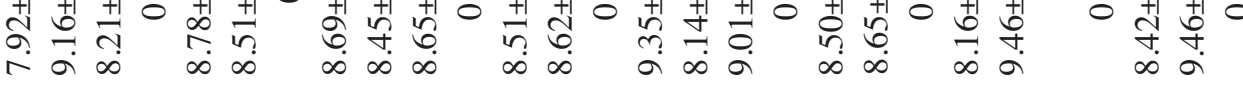

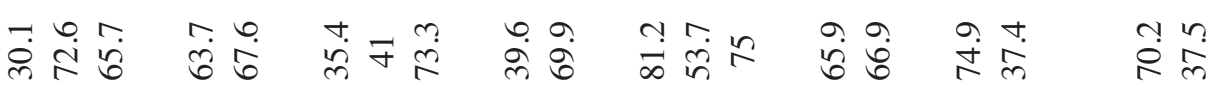
在桒 ă

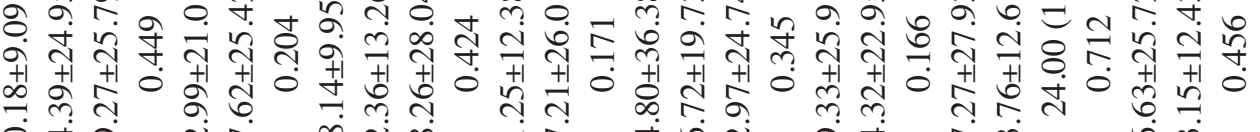

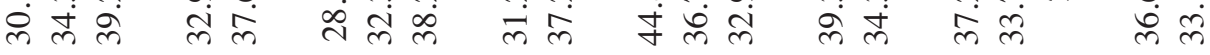

ن্ঠ

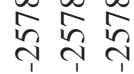

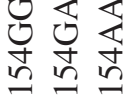
当
己ृ

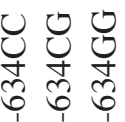

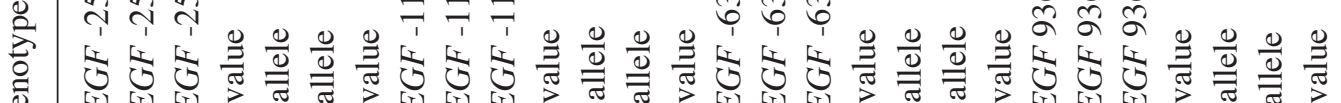

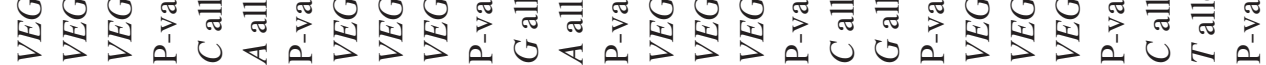


Table VI. Statistical powers of genetic associations in the present case-control study.

\begin{tabular}{|c|c|c|c|c|c|c|}
\hline \multirow[b]{2}{*}{ Genotype } & \multirow[b]{2}{*}{ Model } & \multirow[b]{2}{*}{ Reference type } & \multicolumn{2}{|c|}{ Total RIFs } & \multicolumn{2}{|c|}{$\geq 4$ RIFs } \\
\hline & & & AOR $(95 \% \mathrm{CI})$ & Statistical power $(\%)$ & AOR $(95 \% \mathrm{CI})$ & Statistical power $(\%)$ \\
\hline \multirow[t]{3}{*}{$V E G F-2578 \mathrm{C}>\mathrm{A}$} & Additive & $-2578 \mathrm{CC}$ & $1.21(0.84-1.75)$ & 27.94 & $1.39(0.91-2.12)$ & 58.78 \\
\hline & Dominant & $-2578 \mathrm{CC}$ & $1.12(0.71-1.75)$ & 14.7 & $1.23(0.72-2.10)$ & 28.02 \\
\hline & Recessive & $-2578 \mathrm{CC}$ & $2.02(0.85-4.83)$ & 99.98 & $2.77(1.10-7.02)$ & 99.99 \\
\hline \multirow[t]{3}{*}{$V E G F-1154 \mathrm{G}>\mathrm{A}$} & Additive & $-1154 \mathrm{GG}$ & $1.17(0.78-1.75)$ & 24.42 & $1.34(0.84-2.12)$ & 49.69 \\
\hline & Dominant & $-1154 G G$ & $1.22(0.75-1.99)$ & 36.6 & $1.42(0.81-2.50)$ & 64.89 \\
\hline & Recessive & $-1154 G G$ & $1.15(0.37-3.62)$ & 21.23 & $1.52(0.44-5.25)$ & 80.35 \\
\hline \multirow[t]{3}{*}{$V E G F-634 \mathrm{C}>\mathrm{G}$} & Additive & $-634 \mathrm{CC}$ & $1.56(1.10-2.19)$ & 94.49 & $1.95(1.28-2.98)$ & 99.25 \\
\hline & Dominant & $-634 C C$ & $2.03(1.02-4.05)$ & 99.91 & $3.16(1.19-8.37)$ & 100.00 \\
\hline & Recessive & $-634 \mathrm{CC}$ & $1.65(1.03-2.65)$ & 94.79 & $2.10(1.22-3.64)$ & 99.85 \\
\hline \multirow[t]{3}{*}{$V E G F$ 936C $>\mathrm{T}$} & Additive & $936 \mathrm{CC}$ & $1.00(0.64-1.56)$ & 5.0 & $1.15(0.69-1.93)$ & 16.07 \\
\hline & Dominant & $936 \mathrm{CC}$ & $1.08(0.66-1.75)$ & 8.38 & $1.33(0.76-2.32)$ & 47.53 \\
\hline & Recessive & $936 \mathrm{CC}$ & $0.32(0.04-2.86)$ & 100.0 & NA & \\
\hline
\end{tabular}

AORs and P-values were adjusted by age and body mass index. AOR, adjusted odds ratio; CI, confidence interval; RIF, recurrent implantation failure; NA, not applicable; VEGF, vascular endothelial growth factor.
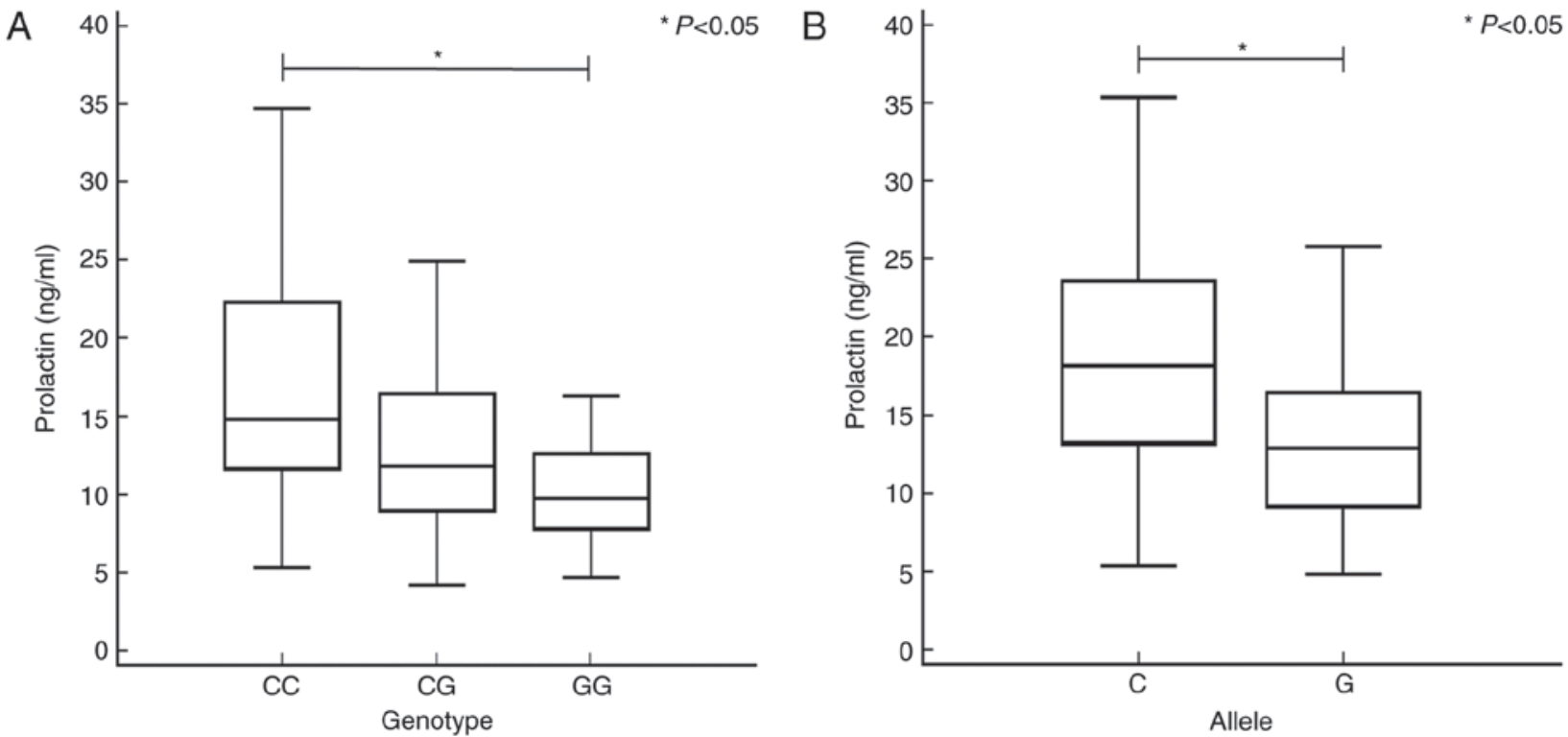

Figure 2. Association between differences in PRL levels and $V E G F-634 \mathrm{C}>\mathrm{G}$ in patients with recurrent implantation failure. Data was analyzed using one-way analysis of variance with a post-hoc Scheffé test for all pairwise comparisons or Student's t-test for each $V E G F-634 C>G$ genotype and allele, respectively. (A) PRL levels in the serum differed significantly $(\mathrm{P}<0.05)$ between patients with the VEGF -634CC [median (range): 14.81 (5.30-34.72)] and -GG [9.77 (4.73-17.40)] genotypes. (B) Patients with the VEGF -634G allele had significantly lower PRL levels compared with patients with the $-634 \mathrm{C}$ allele. "P<0.05. PRL, prolactin; VEGF, vascular endothelial growth factor.

In conclusion, the $-2578 \mathrm{C}>\mathrm{A},-1154 \mathrm{G}>\mathrm{A}$ and $-634 \mathrm{C}>\mathrm{G}$ polymorphisms in the $V E G F$ promoter region were associated with the occurrence of RIF. The results revealed an association between the VEGF -634C $>$ G polymorphism and serum PRL levels. However, further studies of the VEGF promoter polymorphisms involving an independent randomized-controlled population are required to confirm these results. Additionally, the results of the present study warrant additional studies to elucidate the functional role of $V E G F$ promoter polymorphisms in the RIF etiologies. Therefore, the present study indicates that the VEGF -2578AA genotype, -634G allele and $-2578 \mathrm{~A} /-1154 \mathrm{~A} /-634 \mathrm{G} / 936 \mathrm{C}$ haplotype may be utilized as biomarkers for patients with RIF. However, further studies are required to confirm this.

\section{Acknowledgements}

The present study was supported by the Korea Health Technology R\&D Project from the Ministry of Health \& Welfare, Republic of Korea (grant no. HI15C1972010015). 


\section{References}

1. Coughlan C, Ledger W, Wang Q, Liu F, Demirol A, Gurgan T, Cutting R, Ong K, Sallam H and Li TC: Recurrent implantation failure: Definition and management. Reprod Biomed Online 28: 14-38, 2014.

2. Polanski LT, Baumgarten MN, Quenby S, Brosens J, Campbell BK and Raine-Fenning NJ: What exactly do we mean by 'recurrent implantation failure'? A systematic review and opinion. Reprod Biomed Online 28: 409-423, 2014

3. Margalioth EJ, Ben-Chetrit A, Gal M and Eldar-Geva T: Investigation and treatment of repeated implantation failure following IVF-ET. Hum Reprod 21: 3036-3043, 2006.

4. Tan BK, Vandekerckhove P, Kennedy R and Keay SD: Investigation and current management of recurrent IVF treatment failure in the UK. BJOG 112: 773-780, 2005.

5. Valdes CT, Schutt A and Simon C: Implantation failure of endometrial origin: It is not pathology, but our failure to synchronize the developing embryo with a receptive endometrium. Fertil Steril 108: 15-18, 2017.

6. Wei P, Yu FQ, Chen XL, Tao SX, Han CS and Liu YX: VEGF, $\mathrm{bFGF}$ and their receptors at the fetal-maternal interface of the rhesus monkey. Placenta 25: 184-196, 2004.

7. Licht P, Russu V, Lehmeyer S, Wissentheit T, Siebzehnrehn E and Wildt L: Cycle dependency of intrauterine vascular endothelial growth factor levels is correlated with decidualization and corpus luteum function. Fertil Steril 80: 1228-1233, 2003.

8. Sugino N, Kashida S, Takiguchi S, Nakamura Y and Kato H: Induction of superoxide dismutase by decidualization in human endometrial stromal cells. Mol Hum Reprod 6: 178-184, 2000.

9. Sugino N, Kashida S, Karube-Harada A, Takiguchi S and Kato $\mathrm{H}$ : Expression of vascular endothelial growth factor (VEGF) and its receptors in human endometrium throughout the menstrual cycle and in early pregnancy. Reproduction 123 : 379-387, 2002.

10. Kapiteijn K, Koolwijk P, van der Weiden RM, van Nieuw AG, Plaisier M, van Hinsbergh VW and Helmerhorst FM: Human embryo-conditioned medium stimulates in vitro endometrial angiogenesis. Fertil Steril 85: 1232-1239, 2006.

11. Ben Ali Gannoun M, Al-Madhi SA, Zitouni H, Raguema N, Meddeb S, Hachena Ben Ali F, Mahjoub T and Almawi WY: Vascular endothelial growth factor single nucleotide polymorphisms and haplotypes in pre-eclampsia: A case-control study. Cytokine 97: 175-180, 2017.

12. Brogan IJ, Khan N, Isaac K, Hutchinson JA, Pravica V and Hutchinson IV: Novel polymorphisms in the promoter and 5 ' UTR regions of the human vascular endothelial growth factor gene. Hum Immunol 60: 1245-1249, 1999.

13. Koukourakis MI, Papazoglou D, Giatromanolaki A, Bougioukas G, Maltezos E and Siviridis E: VEGF gene sequence variation defines VEGF gene expression status and angiogenic activity in non-small cell lung cancer. Lung Cancer 46: 293-298, 2004.

14. Renner W, Kotschan S, Hoffmann C, Obermayer-Pietsch B and Pilger E: A common $936 \mathrm{C} / \mathrm{T}$ mutation in the gene for vascular endothelial growth factor is associated with vascular endothelial growth factor plasma levels. J Vasc Res 37: 443-448, 2000.

15. Watson CJ, Webb NJ, Bottomley MJ and Brenchley PE: Identification of polymorphisms within the vascular endothelial growth factor (VEGF) gene: Correlation with variation in VEGF protein production. Cytokine 12: 1232-1235, 2000.

16. Wongpiyabovorn J, Hirankarn N, Ruchusatsawat K, Yooyongsatit S, Benjachat T and Avihingsanon Y: The association of single nucleotide polymorphism within vascular endothelial growth factor gene with systemic lupus erythematosus and lupus nephritis. Int J Immunogenet 38: 63-67, 2011.

17. Cheng D, Hao Y, Zhou W and Ma Y: Vascular endothelial growth factor $+936 \mathrm{C} / \mathrm{T},-634 \mathrm{G} / \mathrm{C},-2578 \mathrm{C} / \mathrm{A}$ and $-1154 \mathrm{G} / \mathrm{A}$ polymorphisms with risk of preeclampsia: A meta-analysis. PLoS One 8: e78173, 2013

18. Su MT, Lin SH and Chen YC: Genetic association studies of angiogenesis- and vasoconstriction-related genes in women with recurrent pregnancy loss: A systematic review and meta-analysis. Hum Reprod Update 17: 803-812, 2011.

19. Li YZ, Wang LJ, Li X, Li SL, Wang JL, Wu ZH, Gong L and Zhang XD: Vascular endothelial growth factor gene polymorphisms contribute to the risk of endometriosis: An updated systematic review and meta-analysis of 14 case-control studies. Genet Mol Res 12: 1035-1044, 2013.
20. Boudjenah R, Molina-Gomes D, Wainer R, Mazancourt P, Selva J and Vialard F: The vascular endothelial growth factor $(\mathrm{VEGF})+405 \mathrm{G} / \mathrm{C}$ polymorphism and its relationship with recurrent implantation failure in women in an IVF programme with ICSI. J Assist Reprod Genet 29: 1415-1420, 2012.

21. Goodman C, Jeyendran RS and Coulam CB: Vascular endothelial growth factor gene polymorphism and implantation failure. Reprod Biomed Online 16: 720-723, 2008.

22. Goodman C, Jeyendran RS and Coulam CB: P53 tumor suppressor factor, plasminogen activator inhibitor and vascular endothelial growth factor gene polymorphisms and recurrent implantation failure. Fertil Steril 92, 494-498, 2009.

23. Vagnini LD, Nascimento AM, Canas Mdo C, Renzi A, Oliveira-Pelegrin GR, Petersen CG, Mauri AL, Oliveira JA, Baruffi RL, Cavagna M and Franco JG Jr: The relationship between vascular endothelial growth factor $1154 \mathrm{G} / \mathrm{A}$ polymorphism and recurrent implantation failure. Med Princ Pract 24: 533-537, 2015.

24. Vagnini LD, Nascimento AM, Canas Mdo C, Renzi A, Oliveira-Pelegrin GR, Petersen CG, Mauri AL, Oliveira JB, Baruffi RL, Cavagna $\mathrm{M}$, et al: The relationship between vascular endothelial growth factor $1154 \mathrm{G} / \mathrm{A}$ polymorphism and recurrent implantation failure. Med Princ Pract 24: 533-537, 2015.

25. Jung YW, Kim JO, Rah H, Kim JH, Kim YR, Lee Y, Lee WS and Kim NK: Genetic variants of vascular endothelial growth factor are associated with recurrent implantation failure in Korean women. Reprod Biomed Online 32: 190-196, 2016.

26. Barch MJ, Knutsen T and Spurbeck JL: The AGT Cytogenetics Laboratory Manual. 3rd edition. Lippincott-Raven Publishers, New York, NY, 1997.

27. Jeon YJ, Choi YS, Rah HC, Choi Y, Yoon TK, Choi DH and Kim NK: The reduced folate carrier-1 (RFC1 696T $>$ C) polymorphism is associated with spontaneously aborted embryos in Koreans. Genes Genom 33: 223-228, 2011.

28. Lockshin MD, Kim M, Laskin CA, Guerra M, Branch DW, Merrill J, Petri M, Porter TF, Sammaritano L, Stephenson MD, et al: Prediction of adverse pregnancy outcome by the presence of lupus anticoagulant, but not anticardiolipin antibody, in patients with antiphospholipid antibodies. Arthritis Rheum 64: 2311-2318, 2012.

29. Middeldorp S and van Hylckama Vlieg A: Does thrombophilia testing help in the clinical management of patients? $\mathrm{Br} \mathrm{J}$ Haematol 143: 321-335, 2008

30. Choi DH, Kim EK, Kim KH, Lee KA, Kang DW, Kim HY, Bridges $\mathrm{P}$ and Ko CM: Expression pattern of endothelin system components and localization of smooth muscle cells in the human pre-ovulatory follicle. Hum Reprod 26: 1171-1180, 2011.

31. Kabir S, Shahriar M, Kabir ANMH and Uddin MG: High salt SDS-based method for the direct extraction of genomic DNA from three different gram-negative organisms. CDR J 1: 57-64, 2006.

32. Hong EP, Park JW, Suh JG and Kim DH: Effect of interactions between genetic polymorphisms and cigarette smoking on plasma triglyceride levels in elderly Koreans: The hallym aging study. Genes Genom 37: 173-181, 2015.

33. Zhang L, Liu C, Xu K and Chen J: Association between PNPLA3 rs738409 polymorphism and hepatocellular carcinoma risk: An updated meta-analysis. Genes Genom 38: 831-839, 2016.

34. Chekmenev DS, Haid C and Kel AE: P-Match: Transcription factor binding site search by combining patterns and weight matrices. Nucleic Acids Res 33: W432-W437, 2005.

35. Cao D, Jin C, Ren M, Lin C, Zhang X and Zhao N: The expression of Gli3, regulated by HOXD13, may play a role in idiopathic congenital talipes equinovarus. BMC Musculoskelet Disord 10: $142,2009$.

36. Lambrechts D, Storkebaum E, Morimoto M, Del-Favero J, Desmet F, Marklund SL, Wyns S, Thijs V, Andersson J, van Marion I, et al: VEGF is a modifier of amyotrophic lateral sclerosis in mice and humans and protects motoneurons against ischemic death. Nat Genet 34: 383-394, 2003.

37. Shahbazi M, Fryer AA, Pravica V, Brogan IJ, Ramsay HM, Hutchinson IV and Harden PN: Vascular endothelial growth factor gene polymorphisms are associated with acute renal allograft rejection. J Am Soc Nephrol 13: 260-264, 2002. 
38. Hansen TF, Spindler KG, Lorentzen KA, Olsen DA, Andersen RF, Lindebjerg J, Brandslund I and Jakobsen A: The importance of $-460 \mathrm{C} / \mathrm{T}$ and $+405 \mathrm{G} / \mathrm{C}$ single nucleotide polymorphisms to the function of vascular endothelial growth factor A in colorectal cancer. J Cancer Res Clin Oncol 136: 751-758, 2010.

39. Awata T, Inoue K, Kurihara S, Ohkubo T, Watanabe M, Inukai K, Inoue I and Katayama S: A common polymorphism in the 5'-untranslated region of the VEGF gene is associated with diabetic retinopathy in type 2 diabetes. Diabetes 51: 1635-1639, 2002

40. Amoli MM, Amiri P, Alborzi A, Larijani B, Saba S and Tavakkoly-Bazzaz J: VEGF gene mRNA expression in patients with coronary artery disease. Mol Biol Rep 39: 8595-8599, 2012.

41. Ruiz de Almodovar C, Lambrechts D, Mazzone M and Carmeliet P: Role and therapeutic potential of VEGF in the nervous system. Physiol Rev 89: 607-648, 2009.

42. Yang B, Cross DF, Ollerenshaw M, Millward BA and Demaine AG: Polymorphisms of the vascular endothelial growth factor and susceptibility to diabetic microvascular complications in patients with type 1 diabetes mellitus. J Diabetes Complications 17: 1-6, 2003.

43. Ben Salem A, Megdich F, Kacem O, Souayeh M, Hachani Ben Ali F, Hizem S, Janhai F, Ajina M, Abu-Elmagd M, Assidi M, et al: Vascular endothelial growth factor (VEGFA) gene variation in polycystic ovary syndrome in a Tunisian women population. BMC Genomics 17: 748, 2016.

44. Corbacho AM, Martínez De La Escalera $G$ and Clapp C: Roles of prolactin and related members of the prolactin/growth hormone/placental lactogen family in angiogenesis. J Endocrinol 173: 219-238, 2002.

45. Goldhar AS, Vonderhaar BK, Trott JF and Hovey RC: Prolactin-induced expression of vascular endothelial growth factor via Egr-1. Mol Cell Endocrinol 232: 9-19, 2005.

46. Malaguarnera L, Imbesi RM, Scuto A, D'Amico F, Licata F Messina A and Sanfilippo S: Prolactin increases HO-1 expression and induces VEGF production in human macrophages. J Cell Biochem 93: 197-206, 2004.

47. Seow KM, Lee WL and Wang PH: A challenge in the management of women with polycystic ovary syndrome. Taiwan J Obstet Gynecol 55: 157-158,2016.
48. Kim YR and Hong SH: Gender-specific association of polymorphisms in the 5'-UTR and 3'-UTR of VEGF gene with hypertensive patients. Genes Genom 37: 551-558, 2015.

49. Tenorio Fd, Simões Mde J, Teixeira VW and Teixeira ÁA: Effects of melatonin and prolactin in reproduction: Review of literature. Rev Assoc Med Bras (1992) 61: 269-274, 2015.

50. Adams NR, Vasquez YM, Mo Q, Gibbons W, Kovanci E and DeMayo FJ: WNK lysine deficient protein kinase 1 regulates human endometrial stromal cell decidualization, proliferation and migration in part through mitogen-activated protein kinase 7. Biol Reprod 97: 400-412, 2017.

51. Yu J, Berga SL, Zou W, Yook DG, Pan JC, Andrade AA, Zhao L, Sidell N, Bagchi IC, Bagchi MK and Taylor RN: IL-1 $\beta$ inhibits connexin 43 and disrupts decidualization of human endometrial stromal cells through ERK1/2 and p38 MAP kinase. Endocrinology: Sep 11, 2017 (Epub ahead of print).

52. Pavone ME, Malpani S, Dyson M and Bulun SE: Altered retinoid signaling compromises decidualization in human endometriotic stromal cells. Reproduction 154: 107-116, 2017.

53. Jikihara $\mathrm{H}$ and Handwerger S: Tumor necrosis factor-alpha inhibits the synthesis and release of human decidual prolactin. Endocrinology 134: 353-357, 1994.

54. Garzia E, Borgato S, Cozzi V, Doi P, Bulfamante G, Persani L and Cetin I: Lack of expression of endometrial prolactin in early implantation failure: A pilot study. Hum Reprod 19: 1911-1916, 2004.

55. Shirota M, Banville D, Ali S, Jolicoeur C, Boutin JM, Edery M, Djiane $\mathrm{J}$ and Kelly PA: Expression of two forms of prolactin receptor in rat ovary and liver. Mol Endocrinol 4: 1136-1143, 1990.

56. Bashir ST, Ishak GM, Gastal MO, Roser JF and Gastal EL: Changes in intrafollicular concentrations of free IGF-1, activin A, inhibin A, VEGF, estradiol and prolactin before ovulation in mares. Theriogenology 85: 1491-1498, 2016.

57. Perks CM, Newcomb PV, Grohmann M, Wright RJ, Mason HD and Holly JM: Prolactin acts as a potent survival factor against C2-ceramide-induced apoptosis in human granulosa cells. Hum Reprod 18: 2672-2677, 2003. 